\title{
Retinoblastoma: Magnetic Isotope Effects Might Make a Difference in the Current Anti-Cancer Research Strategy
}

\author{
Alexander A. Bukhvostov, Anton S. Dvornikov, Kirill V. Ermakov, Pavel B. Kurapov, Dmitry A. Kuznetsov*
}

\begin{abstract}
Human retinoblastoma cells were proven to possess some very unusual DNApol $\beta$ species. Being $23.5 \mathrm{kDa}$ monomers, which itself is not common for the DNApol $\beta$ superfamily members, these chromatin associated proteins manifests most of the DNApol $\beta$-specifc functional peculiarities making them legitimate targets for DNA repair cytostatic inhibitors. Particularly, these tumor specific enzymes were found to be very sensitive to ${ }^{25} \mathrm{Mg}^{2+}-,{ }^{43} \mathrm{Ca}^{2+}$ - and ${ }^{67} \mathrm{Zn}^{2+}$-promoted magnetic isotope effects (MIE) caused a marked DNA sequence growth limitation as well as a formation of the size-invalid, i.e. too short in length, DNA fragments, totally inappropriate for the DNA repair purpose. This MIE-DNApol $\beta$ match may serve a starting point for further move towards the paramagnetic path in current developments of anti-cancer strategies.
\end{abstract}

\section{KEYWORDS}

retinoblastoma; magnetic isotope effects (MIE); DNA repair

\section{AUTHOR AFFILIATIONS}

School of Biomedicine, Faculty of Medicine, N. I. Pirogoff Russian National Research Medical University, Moscow, Russia

* Corresponding author: School of Biomedicine, Faculty of Medicine, N. I. Pirogoff Russian National Research Medical University, Ostrovityanov St. 1, Moscow 119997, Russia; e-mail: kuznano@mail.ru

Received: 30 March 2016

Accepted: 27 June 2017

Published online: 5 October 2017

Acta Medica (Hradec Králové) 2017; 60(2): 93-96

https://doi.org/10.14712/18059694.2017.101

(C) 2017 The Authors. This is an open-access article distributed under the terms of the Creative Commons Attribution License (http://creativecommons.org/licenses/by/4.0), which permits unrestricted use, distribution, and reproduction in any medium, provided the original author and source are credited. 


\section{INTRODUCTION}

As seen from a variable data obtained in the past ten years, some certain epigenic factors such as the DNA repair damage are indeed critical for efficiency of any attempt related to the anti-retinoblastoma treatment results $(1,2)$. Thus, the DNA replication and transcription errors, frequently occurring in most cancers, are usually expected to be removed which is the requirement for malignant cell survival (3). This in itself attracts attention to DNA polymerases beta (DNApol $\beta$, EC 2.7.7.7) known for their crucial role in the DNA base excision repair $(1,3)$. Being overexpressed in many variable neoplasmas, these enzymes were found to be a part of the firm positive correlation between (a) their expression/activity patterns and (b) a degree of negative outcome concerning a fatal clinical prognosis in cancer patients (4).

It makes these enzymes the "legitimate targets" for their specific inhibitors making a cancer cell deprived of the DNA repair related survival capabilities (1-4). A magnetic isotope effect (MIE) promoting ions of bivalent metals may play a role of such inhibitors due to their capabilities to dismiss/substitute an endogenous $\mathrm{Mg}^{2+}$ in DNApol $\beta$ catalytic sites. Noteworthy, MIE is nothing but an exclusively powerful impact of "magnetic", i.e. nuclear spin possessing, metal isotope on enzyme catalytic function as compared to effect provided by spinless ("non-magnetic") isotopes of the very same metal (2).

In this study, we have revealed some unusual and pharmacologically promising properties of DNApol $\beta$ targets for the first time isolated here from human retinoblastoma cells.

\section{MATERIALS AND METHODS}

Two human retinoblastoma cell lines, WERI-RB-1A and Y79 (both purchased from the RAS Institute for Cytology, St. Petersburg, Russia), were cultured under normal conditions; a routine MTT-based proliferation assay was performed to monitor over the culture status. Chromatin-associated DNApol $\beta$ fraction was isolated from the cell lysate samples under the conditions preserving native proteins using our slightly modified technique consisting in a subsequent phenol-chloroform/ammonium sulfate treatment followed by the gel filtration on TOYOPEARL HW 55F column (5). For the DNApol $\beta$ catalytic activity measurements, an incorporation of (Methyl-1,2- ${ }^{3} \mathrm{H}$ )dTTP $(90-120 \mathrm{Ci} / \mathrm{mmol}, \mathrm{NE}-$ T520A, NEN) into the nascent enzyme-produced DNA sequences was detected to be expressed then as $\left({ }^{3} \mathrm{H}\right)$ cpmDNA/ $\mathrm{mg}$ protein. The protein amounts were estimated according to (6), the DNA amounts were measured as described in (5). Enzyme inhibitors were tested conventionally: ddTTP, 2.5 $\mu \mathrm{M}$ (Boehringer-Mannheim, Germany); Aphidicolin, $5.0 \mu \mathrm{g} / \mathrm{mL}$ (Serva-Heidelberg, Germany); N-ethyl-melamide, $0.5 \mathrm{mM}$ (Sigma-Aldrich, USA); KCl, $200 \mathrm{mM}$ (Sigma-Aldrich, USA) (5). The kinetic constants, $K_{m}(\mathrm{mM})$ and $k_{\text {cat }}((\mu \mathrm{M} \mathrm{dTTP} / \mathrm{min}) / \mathrm{mg}$ pure enzyme) were estimated by the free dTTP pool depletion rates measured using the HPLC analysis of acetone-soluble fractions of pre- and post-incubated enzyme reaction mixtures in the course of DNApol $\beta$ activity tests (7). Electrophoretic procedures,
SDS-PAGE and agarose gel fractionation, were carried out to evaluate the enzyme molecular mass/purity and the enzyme-produced DNA fragments lengths, respectively (5). To detect the 3',5'-exonuclease activity in purified enzyme samples, a conventional method has been employed (8).

Labeled products and disposal materials: ${ }^{25} \mathrm{MgCl}_{2}$, ${ }^{43} \mathrm{CaCl}_{2}$ and ${ }^{67} \mathrm{ZnCl}_{2}$, all A grade, $96.8-97.7 \%$ isotopic purity, were purchased from Gamma Lab AS (Spain). Tritium labeled DNA precursor, (Methyl-1,2- ${ }^{3} \mathrm{H}$ )dTTP with a specific activity of 90-120 Ci/mmol, NET520A, was purchased from New England Nuclear, Inc., USA. DNAse-free agarose (Helicon Co., UK); ethidium bromide (AppliChem AG, Sweden); single strand DNA markers kit, 30n-550n (SibEnzyme Ltd, Russia); AccuPrep Genomic DNA Extraction Kit (Bioneer Ltd, Korea); and RX5 $\left({ }^{3} \mathrm{H}\right)$ sensitive autoradiography films (Fuji Corp., Japan) were employed.

For all enzyme activity tests, optimal $\left(\mathrm{Me}^{2+}\right)$ values were kept $(2,5)$. The DNA extract aliquots were utilized further for electrophoretic determination of the pol $\beta$ directed DNA chain sizes as well as for total $\left({ }^{3} \mathrm{H}\right)$-radioactivity values in a standard dioxane liquid scintillation system (Wallac 2200LX LS Counter, Wallac OY, Finland). A DNA size estimating electrophoresis performed in 1.8\% PAAG$2.0 \%$ Agarose slab gels was completed with a $\left({ }^{3} \mathrm{H}\right)$-exposed Fuji RX film autoradiography (9).

\section{RESULTS}

Being very similar to each other (Table 1), the enzyme species purified from both cell types tested, were found belonging to the low processivity type as clearly reflected by kinetic constants: WERI-RB-1A, $K_{m}=0.012 \mathrm{mM}, k_{\text {cat }}=$ 0.609 ( $\mu \mathrm{M} \mathrm{dTTP} / \mathrm{min}) / \mathrm{mg}$ enzyme; $\mathrm{Y} 79, K_{m}=0.018 \mathrm{mM}$, $k_{\text {cat }}=0.617(\mu \mathrm{M} \mathrm{dTTP} / \mathrm{min}) / \mathrm{mg}$ enzyme. This is a known DNApol $\beta$-specific property (5).
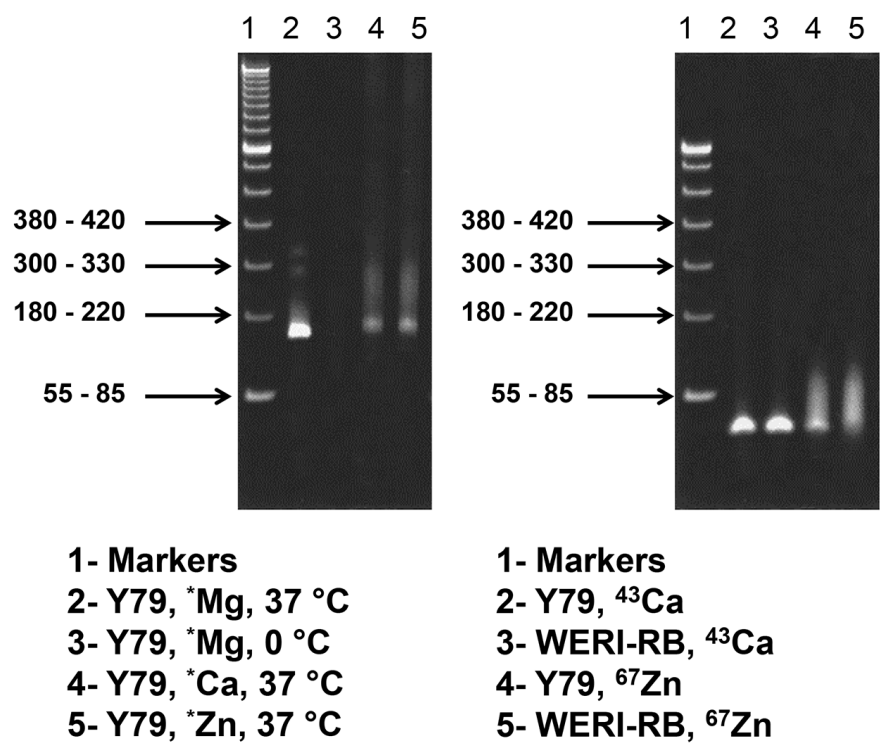

Fig. 1: Polyacrylamide-agarose gel electrophoretic fractionation of the retinoblastoma DNApol $\beta$-processed (3h)DNA fragments. Tritium Autoradiography Patterns.

${ }^{*} \mathrm{Mg},{ }^{*} \mathrm{Ca},{ }^{*} \mathrm{Zn}$ - a natural abundance isotope mixtures tested in enzyme optimized incubation system; ${ }^{25} \mathrm{Mg},{ }^{43} \mathrm{Ca},{ }^{67} \mathrm{Zn}$ - same for the pure paramagnetic metal isotopes. 
Tab. 1: Key catalytic properties of DNApolß species from human retinoblastoma cells.

\begin{tabular}{|c|c|c|c|}
\hline \multirow{2}{*}{\multicolumn{2}{|c|}{ Enzyme Pattern }} & \multicolumn{2}{|c|}{ Cell Type } \\
\hline & & Y79 & WERI-RB \\
\hline \multicolumn{2}{|l|}{ Quaternary structure } & none & none \\
\hline \multicolumn{2}{|l|}{$\mathrm{MW}, \mathrm{kDa}$} & 23.5 & 23.5 \\
\hline \multicolumn{2}{|l|}{$\mathrm{pl}$} & 8.20 & 8.50 \\
\hline \multicolumn{2}{|l|}{$\mathrm{K}_{m^{\prime}} \mu \mathrm{M}(\mathrm{dTTP}$ pool) } & 0.013 & 0.010 \\
\hline \multicolumn{2}{|l|}{$\mathrm{k}_{\text {cat' }} \mu \mathrm{M}([\mathrm{dTTP} / \mathrm{min}] \mathrm{mg}$ protein) } & 0.394 & 0.418 \\
\hline \multicolumn{2}{|l|}{ 3',5' -exonuclease activity } & none & none \\
\hline \multicolumn{2}{|l|}{$\mathrm{KCl}$ effect $(200 \mathrm{mM})$} & $\uparrow 2.2$ & $\uparrow 1.8$ \\
\hline \multicolumn{2}{|l|}{ ddTTP effect $(2.5 \mu M)$} & $\downarrow 28.0$ & $\downarrow 33.8$ \\
\hline \multicolumn{2}{|l|}{ Aphidicolin effect $(5.0 \mu \mathrm{g} / \mathrm{mL})$} & none & none \\
\hline \multicolumn{2}{|c|}{$\mathrm{N}$-ethyl-melamide effect $(0.5 \mathrm{mM})$} & none & none \\
\hline \multirow[t]{3}{*}{ Magnetic Isotope Effect (MIE)* } & ${ }^{25} \mathrm{Mg}^{2+}$ & $\downarrow 1.9$ & $\downarrow 2.2$ \\
\hline & ${ }^{43} \mathrm{Ca}^{2+}$ & $\downarrow 2.7$ & $\downarrow 2.5$ \\
\hline & ${ }^{67} \mathrm{Zn}^{2+}$ & $\downarrow 3.0$ & $\downarrow 2.4$ \\
\hline
\end{tabular}

* MIE value expressed as the specific catalytic activity of DNApol $\beta$ measured in the presence of pure "magnetic", nuclear spin possessing, metal ions corrected to its activity in the presence of the same content of ions of the same element abundant spinless isotopes [11, 15, 16].

The short size (not longer than $300 \mathrm{bp}$ ) of the DNA fragments produced by enzymes we purified, a highly specific diagnostic pattern indicating DNApol $\beta$ catalysis $(3,5)$, has been observed (Figure 1).

A clear negative, inhibitory, 1.9-3.0-fold MIE was estimated for all three nuclear spin possessing ("magnetic") metal isotopes tested in reactions of both tumor specific DNApol $\beta$ species (Table 1).

All measurements were carried out at optimal conditions.

Arrow signs show activation (up) or inhibition (down) observed.

\section{DISCUSSION}

A high resistance to Aphidicolin and $N$-ethyl-melamide along with a marked sensitivity to ddTTP that has been shown simultaneously with the $200 \mathrm{mM}$ (!) KCl-promoted hyperactivation (Table 1) is a most reliable characteristic property for the DNApol $\beta$ family members; a total lack of $3^{\prime}, 5^{\prime}$-exonuclease catalytic activity in our purified enzyme samples is also in a favor to their DNApol $\beta$ nature (3-5).

Apart from a sharp inhibitory magnetic isotope effects (MIE) manifested by all stable paramagnetic isotopes tested (Table 1), these effects promote a significant decrease in lengths of the DNA fragments processed by tumor originated metal dependent DNApol $\beta$ species (Figure 1). This means an obvious incapability of such "abnormally short" DNA chains to get involved into the DNA repair process. So occurring simultaneously with the sharp MIE-induced enzyme suppression, this fact itself makes it possible to consider these short, size-invalid, DNA segments not-fitting their crucial role in the DNA repair based protection of cancer cell. This confirms a concept $(4,5,11,12)$ taking DNApol $\beta$ as a legitimate target for anti-tumor agents since its inhibition deprives the tumor cell of a DNA base-excision repair.

Recognizing the MIE phenomenon as a powerful modulator for matalloenzyme programmed phosphate trans- ferring catalysis in vivo (10) and in vitro (11), it is hardly possible to underestimate its cytostatic potential as long as a MIE-DNApol $\beta$ match leads to a breakdown of the DNA repair related survival of neoplasma. Since physical and biophysical ion-radical mechanism of MIE is no longer enigmatic $(2,10,11)$, we may disclose a fresh insight into not only the processes of replication and reparation of DNA but into some linked areas of molecular pharmacology as well.

In the light of some recent developments proposing the safe-n-convenient nanocontainers for a targeted delivery of paramagnetic bivalent metal cations to cancer cells and tissues $(2,11,12)$, our results might be taken as an attention catching signal we need to optimize the current strategies in retinoblastoma treatment and research.

Last not least, the type of MIE related magnetism, a background of a whole trend of spin-selective biochemistry $(10,11)$, consists in a Coulomb hyperfine coupling between "magnetic" (spin-marked) metal nuclei and a phosphate belonging oxygen inside the ion-radical pair followed by the "magnet" induced singlet-triplet conversion of this pair $(13,14)$. Conventionally, the nuclear spin possessing metal isotopes were labeled as "magnetic" ones in numerous MIE-devoted biochemical reports (2, 10-14). In particular, mechanisms and pharmacological potential of MIE promoted by ${ }^{25} \mathrm{Mg}^{2+},{ }^{43} \mathrm{Ca}^{2+}$ and ${ }^{67} \mathrm{Zn}^{2+}$ in DNApol $\beta$ reaction were in a focus of studies on human myeloblast leukemia cells $(15,16)$. So far, however, this type of tumors was the only malignant objects studied with respect to MIE-DNApol $\beta$ impacts. As per retinoblastoma research, our present work is the first investigation of this kind.

\section{CONCLUSIONS}

A trend making MIE-focused approach to ongoing anti-retinoblastoma clinical and pre-clinical efforts is about to rise now due to a revealed possibility of taking DNApol $\beta$ molecular machinery as a tumor specific target for the controlled 
paramagnetic DNA repair damage. This itself deserve an extensive study for an aim to get some metal stable isotope tool depriving the malignant cells of the DNA repair capabilities required for their aggressive growth and reproduction. Therefore, bivalent metal paramagnetic should be treated as a compound sufficient to contribute to the current retinoblastoma molecular pharmacology studies.

\section{ACKNOWLEDGEMENTS}

The RNRMU MedNanoBioTech Center for Collective Usage (CKP) is gratefully acknowledged for the qualified technical assistance provided in a course of present study.

\section{REFERENCES}

1. Zhang J, Benavente CA, McEvoy J, et al. A novel retinoblastoma therapy from genomic and epigenic analyses. Nature 2012; 481(7381): 329-334.

2. Udvardi L, Loewenhaupt H, Berthault M. Medicinal Paramagnetics. Szeged: Alba Regia, 2017.

3. SungchulJ.MolecularTheory of a Living Cell. New York: Springer, 2012.

4. Martin S, McCabe N, Mullarkey M, et al. Ashworth A. DNA polymerases as potential therapeutic targets in cancers. Cancer Cell 2010; 17: 235-248.

5. Bukhvostov AA, Shatalov OA, Orlov AP, Kuznetsov DA. An atypical DNA polymerase beta overexpressed in human AML/HL-60 malignant cells. J Cancer Sci Therap 2013; 5: 94-99.
6. Fukami T, Uchiyama K, Yoshimura Y, Watanabe T, Nakazawa H. Ultramicro-analysis by use of light-scanning photoacoustic densitometry for electrophoresed protein in human hair. Anal Biochem 1996; 238: 60-64.

7. Kuznetsov DA, Govorkov AV, Zavijalov NV, Sibileva TM, Richter V. Fast estimation of ATP/ADP ratio as a special step in pharmacological and toxicological studies using the cell-free translation systems. J Biochem Biophys Methods 1986; 13: 53-56.

8. Rule GS. Quantitative assay of deoxyribonuclease activity after isoelectric focusing in polyacrylamide gels. Analyt Biochem 1984; 138: 99-106.

9. Katoh R. Analytical Techniques in Biochemistry and Molecular Biology. Berlin - Dortrecht - Heidelberg: Springer, 2011.

10. Buchachenko AL. Why magnetic and electromagnetic effects on biology are ambiguous and contradictory ? Bioelectromagnetics 2016; 37(1): 1-13.

11. Buchachenko AL, Lawler RG. New possibilities for magnetic control of chemical and biochemical reactions. Acc Chem Res 2017; 50: 877884.

12. Orlova MA, Osipova EY, Roumiantsev SA. Effect of ${ }^{67} \mathrm{Zn}$-nanoparticles on leukemic cells and normal lymphocytes. Brit J Med Med Res 2012; 2(1): 21-30.

13. Buchachenko AL. Magnetic Isotope Effect in Chemistry and Biochemistry. New York: Nova Science Publishers, 2009.

14. Buchachenko AL, Kuznetsov DA, Breslavskaya NN. Chemistry of enzymatic ATP synthesis: an insight through the isotope window. Chem Rev 2012; 112: 2042-2058.

15. Buchachenko AL, Orlov AP, Kuznetsov DA, Breslavskaya NN. Magnetic isotope and magnetic field effects on the DNA synthesis. Nucl Acids Res 2013; 41: 8300-8307.

16. Bukhvostov AA, Napolov JK, Buchachenko AL, Kuznetsov DA. A new platform for anti-cancer experimental pharmacology: the DNA repair enzyme affected. Brit J Pharmacol Toxicol 2014; 5: 35-41. 